\title{
Metastatic Eccrine Porocarcinoma with Indolent Clinical Course
}

\section{Klinik Yavaş Seyirli Metastatik Ekrin Porokarsinoma}

\author{
Umut Demirci $^{1}$, Ayşe Demirci ${ }^{1}$, Şebnem Ayva ${ }^{2}$, Uğur Coşkun ${ }^{3}$, İlker Yazıcı ${ }^{4}$, Meltem Baykara $^{5}$, Mustafa \\ Benekli $^{3}$, Süleyman Büyükberber ${ }^{3}$ \\ ${ }^{1}$ Dr. A. Y. Ankara Onkoloji Eğitim Ve Araştırma Hastanesi, Tıbbi Onkoloji Kliniği, Ankara, Türkiye \\ ${ }^{2}$ Kırıkkale Üniversitesi Tıp Fakültesi, Patoloji Bilim Dalı, Kırıkkale \\ ${ }^{3}$ Gazi Üniversitesi Tıp Fakültesi, Tıbbi Onkoloji Bilim Dalı, Ankara \\ ${ }^{4}$ Kırıkkale Üniversitesi Tıp Fakültesi, Plastik Cerrahi Bilim Dalı, Kırıkkale \\ ${ }^{5}$ Sakarya Üniversitesi Eğitim Ve Araştırma Hastanesi, Tıbbi Onkoloji Bölümü, Sakarya
}

DoI: $10.5505 /$ aot.2012.40085

\section{ÖZET}

Ekrin porokarsinoma ekrin ter bezlerinin nadir görülen bir malignitesidir. Standart tedavisi yoktur. Biz burada daha önceden uzun süredir cilt lezyonları olan ileri yaş bir metastatik ekrin porokarsinoma olgusunu sunduk. Özellikle ileri yaş ve asemptomatik hastaların metastatik bile olsa tedavisiz takip edilebileceğini gösterdik.

Anahtar Kelimeler: Ekrin porokarsinom; Malignite; Metastaz; Pozitron emisyon tomografi (PET)

\begin{abstract}
Eccrine porocarcinoma is a rare malignancy of eccrine sweat glands. Standart treatment remains unclear. We presented metastatic eccrine porocarcinoma in advanced age that has a long history of a preexisting skin lesion. We have shown that asymptomatic patients in advanced age can be followed-up without treatment even in metastatic disease.
\end{abstract}

Key words: Eccrine porocarcinoma; Malignancy; Metastasis; Positron emission tomography (PET)

\section{Introduction}

Eccrine porocarcinoma (EP) is a rare malignancy of eccrine sweat glands. It is more common in female and advanced aged over 60 years $(1,2)$. EP has been frequently reported in lower extremity, trunk and head (1). The etiology of EP is unclear, however it may arise de novo or evolve from a preexisting benign eccrine poroma $(1,2)$. Malignant transformation may be characterized by pain, itching, spontaneous bleeding, ulceration, and sudden growth (1). It has a notably risk of locoregional and distant failure (3). Primary curative treatment is wide surgical exision. Treatment modalities have included surgery, chemotherapy and radiation therapy (RT) in metastatic disease. Here in, we present a negleted case whom has a long history of a preexisting skin lesion detected as metastatic EP.

\section{Case Report}

A 76-year-old man admitted with a scaly erythematous patch on the below of left patella with a 13 years history. The lesion was treated with topical agents for a long time. Surgical exision was offered however the patient refused the surgery. In the last few months, the nodular lesion was rapidly growed that measured as $3.5 \mathrm{~cm}$ and became effluent. A wide excision was performed and histological examination demonstrated EP with negative surgical margins. Microscopical investigation showed proliferation of basaloid cells, large poligonal eosinofilic cells and clear cells that mainly confined to the epidermis.

The lesion extended into the dermis with a few areas. There were some cystic areas compatible with cuticles and cellular atypia characterized by bizaar giant cell and brisk mitotic activity. Lymphovascular invasion was seen in a focal area (Fig. 1a,1b). The immunohistochemical (IHC) stain consisted of epithelial membrane antigen (EMA) and carcinoembryonic antigen (CEA) (Fig. 1c,1d). There was no local lymph node involvement in 
his physical examination. However thoracoabdominal computarized tomography (CT) scan showed numerous pulmonary nodules that the largest was $14 \times 9 \mathrm{~mm}$ and a hypodens lesion right lobe of the liver. Positron emission tomography/ computarized tomography (PETCT) showed increased pathological 18-fluoro2-deoxy-D-glucose (18-FDG) uptake in the lung nodules and the cervical lesion (Fig. 2). Because of his age and poor performance status the patient was treated palliative intent without chemotherapy. He has been followed without progression and complaint after 20 months of diagnosis.

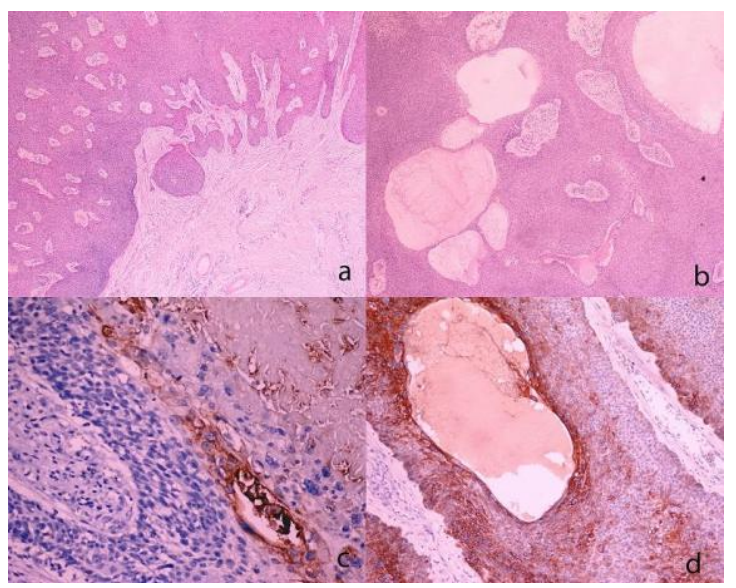

Figure 1: Small basaloid cell proliferation that showed a downward infiltrating growth pattern (H\&E, x40), b. Basaloid cell proliferation with cystic change (H\&E, x40), c. Ductal differentiantion shown by carcinoembryonic antigen staining (CEA, x200), d. Ductal differentiantion shown by epithelial membrane antigen staining (EMA, x100)

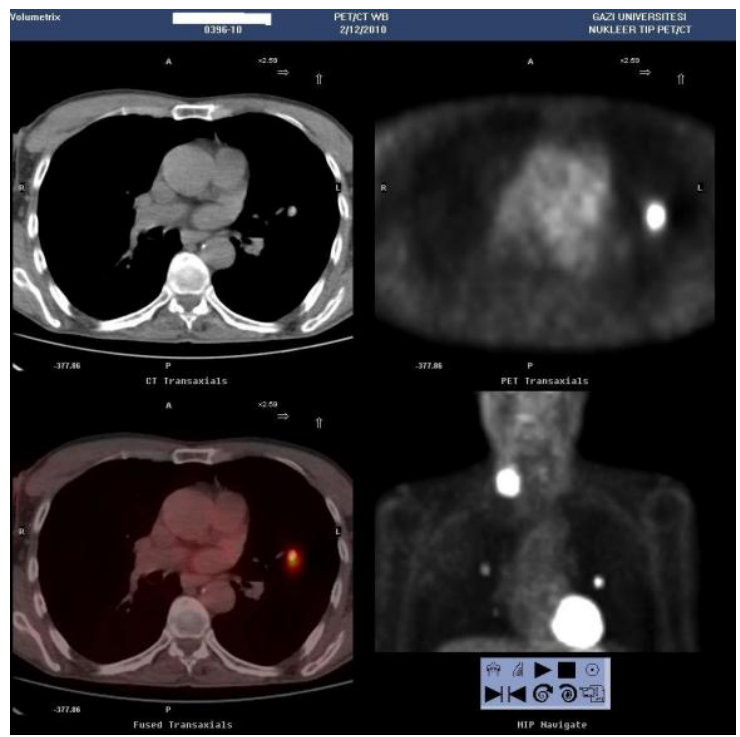

Figure 2: Increased FDG uptake in the lung nodules and the cervical lesion (PET/BT)

Address for CorrespondenceDoç. Dr. Umut Demirci , Ankara Onkoloji Eğitim Ve Araștırma Hastanesi, Tıbbi Onkoloji Kliniği

Available at: www.actaoncologicaturcica.com

\section{Discussion}

EP is a rare skin cancer and usually presents with a solitary slowly growing lesion in lower extremity at older age like our case. The prediagnostic duration of EP is usually a long time, suggesting that the lesion undergoes malignant changes from the preexisting benign eccrine poroma. Our case was awared of this lesion since 13 years and he is a one of the longest latent period in the literature. By this latency, EP was detected as advanced disease consequently.

EP appears red or flesh-coloured various lesions as papular, plaque or ulcerous. It may be mistaken clinically for benign and malign skin lesions such as seborrhoeic keratosis and nonmelanoma skin cancers (3-5). Similarly, we thought usual skin cancer as a differantial diagnosis in this case. The diagnosis of EP is rendered on histopathologic features such as mitosis, atypia and invasion. IHC staining such as CEA, EMA and periodic acid schiff (PAS) may support the diagnose of EP however not rule out. Besides our pathologic examination showed CEA and EMA positivity.

Locoregional recurrences were developed in $20 \%$ of cases, solid organ metastases in $10 \%$ (1). We evaluated the dissemination of disease by PET/CT like a recent study (6). PET/CT can be advised especially in late case and locally advanced disease. In our case, multiple pulmonary metastasis and a cervical lypmh node metastasis were established. Wide surgical excision of the primary tumor in early stage is essential and frequently curative (70-80\%), adjuvant RT or chemotherapy remain unclear. Chemotherapy can be an option for symptomatic disease nonetheless EP considered resistant to many cytotoxic agents. Previously IFN- $\alpha$ and isotretinoin had been used (6-10). Perez-Garcia et al. suggested anthracycline-based or combination chemotherapy with docetaxel, paclitaxel, 5-FU and cisplatin in the first-line treatment of advanced EP (6). We did not performed chemotherapy because of poor performance status and advanced age. However, in this case's survival reached 20 months without treatment.

In conclusion, we suggested follow-up without treatment in asymptomatic metastatic 
disease especially in advanced age because of indolent clinical course.

\section{Conflict of Interest: None}

\section{References}

1. Brown CW JR, Dy LC. Eccrine porocarcinoma. Dermatol Ther 2008;21:433-8

2. Affleck AG, Bong JL, Ostroumova MA, Leach IH, Perks AG, Varma S. Ecrine porocarcinoma, Dermatol Online J 2006;12:17

3. Wick MR, Goellner JR, Wolfe JT 3rd, Su WP Adnexal carcinomas of the skin. I. Eccrine carcinomas. Cancer 1985;56:1147-62

4. Chang NC, Tsai KB. Ecrine porocarcinoma of the auricle: a case report. Kaohsiung J Med Sci 2009;25:401-4

5. Attili SK, Evans A, Fleming CJ. Recurrent pigmented ecrine porocarcinoma presenting as carcinoma erysipeloides. Clin Exp Dermatol 2009;34;493-5
6. Perez-Garcia J, Morales R, Valverde CM, et al. Eccrine porocarcinoma presenting with scrotal lymphedema: a case report and review of systemic treatment. Ann Oncol 2010;21:907

7. Gutermuth J, Audring H, Voit C, Trefzer U, Haas N, Antitumour activity of paclitaxel and interferonalpha in a case of metastatic eccrine porocarcinoma. J Eur Acad Dermatol Venereol 2004;18:477-9

8. Plunkett TA, Hanby AM, Miles DW, Rubens RD, Metastatic eccrine porocarcinoma: Response to docetaxel (Taxotere) chemotherapy, Ann Oncol 2001;12:411-4

9. Piedbois P, Breau JL, Morere JF, Israel L. Sweat gland carcinoma with bone and visceral metastases. Prolonged complete remission lasting 16 months as a result of chemotherapy. Cancer 1987;60:170-2

10. Coonley CJ, Schauer P, Kelsen DP, Sordillo P, Huvos AG, Chemotherapy of metastatic sweat gland carcinoma. Am J Clin Oncol 1985;8:307-11 